\title{
Assessing bovine babesiosis in Rhipicephalus (Boophilus) microplus ticks and 3 to 9-month-old cattle in the middle Magdalena region, Colombia ${ }^{1}$
}

\author{
Sandra Ríos-Tobón², Lina A. Gutiérrez-Builes ${ }^{2,3}$ and Leonardo A. Ríos-Osorio ${ }^{2 *}$
}

\begin{abstract}
Ríos-Tobón S., Gutiérrez-Builes L.A. \& Ríos-Osorio L.A. 2014. Assessing bovine babesiosis in Rhipicephalus (Boophilus) microplus ticks and 3 to 9-monthold cattle in the middle Magdalena region, Colombia. Pesquisa Veterinária Brasileira 34(4):313-319. Grupo de Investigación en Microbiología Veterinaria, Escuela de Microbiología, Universidad de Antioquia, Calle 67 no. 53-108, Lab. 5-437, Medellín, Colombia. E-mail:mleonardo@udea.edu.co

Babesia sp. is a protozoan hemoparasite that affects livestock worldwide. The Colombian Middle Magdalena is an enzootic region for babesiosis, but there is no previous research providing detail on its transmission cycle. This study aims to assess some Babesia sp. infection indicators in cattle and ticks from the area, by using direct microscopic and molecular techniques to detect the infection. In the cattle, 59.9\% and $3.4 \%$ positivity values for $B$. bigemina and mixed infection (B. bovis $+B$. bigemina) were found respectively. In ticks, the positivity of B. bigemina reached $79.2 \%$ and $9.4 \%$ for the mixed infection. The degree of infestation in the region was 3.2 ticks per bovine. There was positive correlation between tick control acaricide frequencies and infestation in bovines. This leads us to infer that control periodicity greater than 90 days, in stable zones, is an abiotic factor that benefits the acquisition of protective immunity in calves, the natural control of the infection and eventual disease absence. It is necessary to monitor the disease by applying new entomological and parasitological indicators showing the complexity of this phenomenon.
\end{abstract}

INDEX TERMS: Babesia sp., babesiosis, cattle, tick-borne diseases, Rhipicephalus (Boophilus) microplus.

\section{INTRODUCTION}

Bovine Babesiosis is a disease caused by intraerythrocytic protozoal parasite of the order Piroplasmida, phylum Apicomplexa, of the genus Babesia, widely found in tropical and subtropical areas (Alonso et al. 1992). Most cases of the disease in bovines are caused by Babesia bigemina and Babesia bovis. In Latin America, they are transmitted by ticks of the species Rhipicephalus (Boophilus) microplus (Ravindran et al. 2006). These ectoparasites infest about $80 \%$ of bovines worldwide, causing losses close to 3,000 million dolars per year (Melendez \& Forlano 1996).

\footnotetext{
${ }^{1}$ Received on September 25, 2013.

Accepted for publication on February 7, 2014.

${ }^{2}$ Grupo de Investigación en Microbiología Veterinaria, Escuela de Microbiología, Universidad de Antioquia, Calle 67 No. 53-108, Laboratorio Central de Investigaciones 5-437, Medellín, Colombia. *Corresponding author: mleonardo@udea.edu.co

${ }^{3}$ Escuela de Ciencias de la Salud, Facultad de Medicina, Universidad Pontificia Bolivariana, Sede Robledo Medellín, Calle 78B no.72A-109, Medellín, Colombia. E-mail: lina.gutierrezb@upb.edu.co
}

The endemic condition of bovine babesiosis in a specific geographic region is related with presence of a vector capable to transmit the infection, and the enzootic stability condition depends of the interaction established between tick, parasite and bovine. As a result, there is an ideal situation for a bovine to be infested and infected by ticks, at such levels that lead to protective immunity in the absence of signs and symptoms of the disease (Alonso et al. 1992, Barreira et al. 2005). In these endemic zones, calves are generally infected during the first months after birth, while they possess a strong innate immunity (Barros et al. 2005). After recovery from acute disease, young animals may develop a subclinical form of the infection after suffering it by several months, and develop a new condition of reservoir for the parasite vector as a consequence (Oliveira et al. 2008). This epizootiological situation has traditionally been studied by identifying IgG antibodies in 3 to 9-month-old bovines, overlooking other factors such as parasitological infection indicators in vectors and bovines, together with infestation degree in bovines considered important in 
the specification of an enzootically stable or unstable area. These ignored factors could be used to understand the behavior of bovine babesiosis because of their incidence in the parasite's life cycle (Melendez \& Forlano 1996, Cantu et al. 2007).

In Colombia, the presence of the vector and the parasite in an endemic area for bovine babesiosis depend on certain geographical and environmental conditions. The area needs to be located under 2200 meters above the sea level (m.a.s.l.); its temperature should range from 28 to $32^{\circ} \mathrm{C}$; and it should have an 80 to $90 \%$ relative humidity (Alonso et al. 1992). In particular, the Middle Magdalena region is located in a tropical rainforest area; its average temperature is $27^{\circ} \mathrm{C}$; and it is 125 m.a.s.l. Its ecological conditions enable the vector developmental cycle, together with the fact that farming milk, meat and dual-purpose cattle constitutes the main economic activity in the region (Gómez 2005). Previous research on Babesia bovis and Babesia bigemina transmission has been carried out in the region, finding enzootic stability levels by means of IgG antibodies evaluation in 3 to 9-month-old calves (Ríos et al. 2010). However, the activity of other entomological and parasitological indicators that would allow understanding the parasite behavior in ticks and the influence of biotic and abiotic factors on its life cycle is still unknown.

All things considered, this research aims to identify some bovine babesiosis entomological and parasitological indicators in ticks Riphicephalus microplus and 3 to 9-month-old cattle in the Middle Magdalena area in Colombia, by means of entomological and parasitological direct microscopic and molecular techniques.

\section{MATERIALS AND METHODS}

Study design and area. A descriptive study with representative and non-probability sampling was carried out. The reference population for a survey on bovine brucellosis carried out in 2006 $-13,800$ bovines- in 200 herds in the Middle Magdalena area, was considered for the sample size. These resources were provided by the administration at the Regional Cooperative Society of Livestock Farmers (COREGAN) in the Middle Magdalena Region. The average population in 9 herds (503) was established as the universe; the calculated sample size (n) was 218 bovines (Epi-info 2004), based on a confidence level (z) of $95 \%$, a sampling error (e) of $5 \%$ and a variance $(\mathrm{p})$ of 0.5 .

This study was conducted in 9 herds, where cattle is farmed for beef, milk, dual and exhibition purposes. The herds are located in the Colombian Middle Magdalena region, in the area between the municipalities of Puerto Berrio (Antioquia), located $7^{\circ} 6^{\circ} 29^{\prime}$ $35^{\prime \prime} \mathrm{N}$ and $75^{\circ} 74^{\circ} 24^{\prime} 26^{\prime \prime} \mathrm{W}$, with an area of $1.184 \mathrm{Km}^{2}$, and Cimitarra (Santander), located $06^{\circ} 19^{\prime} 00^{\prime \prime} \mathrm{N}$ and $73^{\circ} 57^{\prime} 00^{\prime \prime} \mathrm{W}$, in an area of $3.165,60 \mathrm{Km}^{2}$. Both municipalities have an average annual rainfall of 2,500 to 3,000 $\mathrm{mm}^{3}$ (Gómez 2005). The herds selected for this study are identified like CB, EA, SL, SA, CN, LC, LL, B and LA (Fig.1).

Clinical epizootiological survey. An epizootiological survey was carried out with the purpose of evaluating the signs and symptoms of the infection, parasite burden and epidemiologic factors related with the presence of the disease in the area, namely, age of animals, sex, farming system, acaricides used, and its frequency. This survey was validated in a previous study on enzootic stability conducted in the region (Ríos et al. 2010).

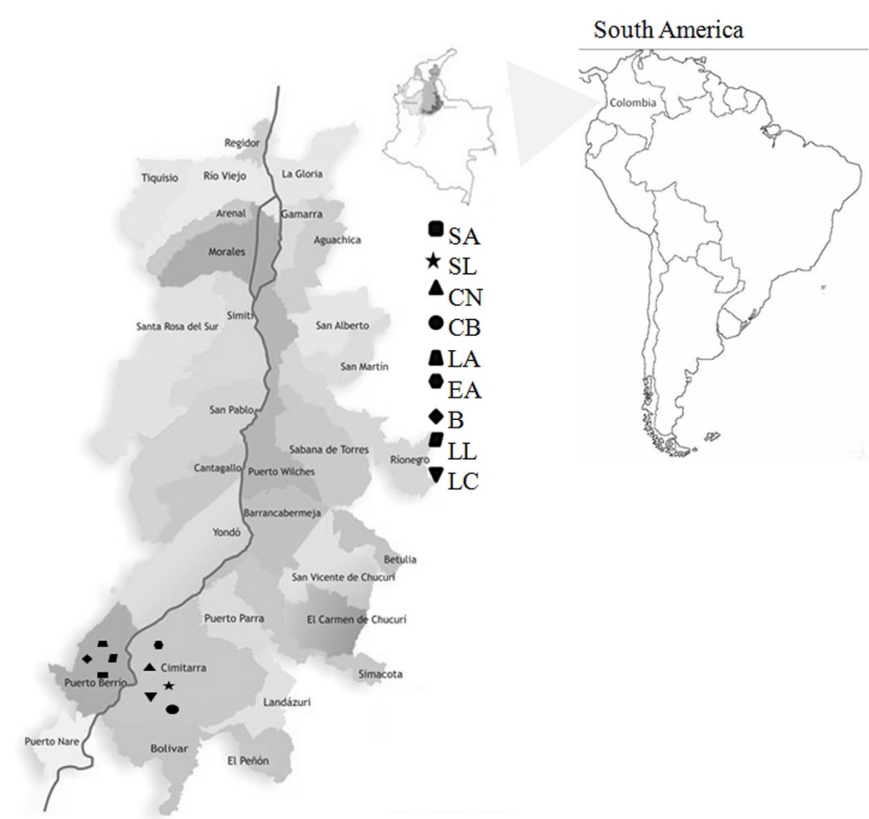

Fig.1. Distribution of herds location in the middle Magdalena area, Colombia.

Cattle blood samples collection and procedures. The samples for this study were extracted from 237 calves, aged between 3 and 9 months old and born in each farm. A sample of $5 \mathrm{ml}$ of blood was taken from each calf's jugular vein after demobilizing the animal. The samples were collected in Vacuette ${ }^{\circledR}$ tubes, into EDTA anticoagulant. In addition, DNA extraction was carried out through salting out procedures, on $200 \mathrm{ul}$ of blood in anticoagulant EDTA, contained in $1.5 \mathrm{ml}$ tubes. The extracted product was resuspended in $1 X$ TE buffer and stored at $-20^{\circ} \mathrm{C}$ until used (Villafañe et al. 2009).

Tick samples collection and procedures, Female engorged $R$. microplus ticks larger than or equal to $4.5 \mathrm{~mm}$ were collected from the sagittal plane of each animal, according to the technique proposed by Álvarez et al. (2003). After collection, the ticks were incubated for 7 days at room temperature to enable the completion of the parasite cycle into the vector. This procedure was performed in wide-mouthed plastic containers, with wet gauze at bottom to guarantee $80 \%$ to $90 \%$ humidity, and that were properly labeled with the code on each calf (Morzaria et al 1992; Guglielmone et al 1996). Each tick was stored at $-20^{\circ} \mathrm{C}$ for DNA extraction. Four ticks per sampled animal were used for DNA extraction, according to the protocol optimized by Rosero et al. (2010). However, the protocol was modified by sectioning each tick in small pieces with a sterile scalpel blade, before proceeding to mechanical maceration, in order to optimize the DNA extraction process. The DNA obtained was resuspended in $1 \mathrm{X}$ TE buffer and stored at $-20^{\circ} \mathrm{C}$ for its amplification using PCR.

Babesia bovis and Babesia bigemina molecular identification in cattle and ticks. The subunit 18S rRNA gene partial sequence of Babesia bovis and Babesia bigemina (275 bp y 175 $\mathrm{bp}$, respectively) were amplified by polymerase chain reaction (multiplex PCR). The primers used for B. bovis and B. bigemina 18S rRNA amplification were the ones described by Adham et al. (2009). Sterile ultrapure water (Mili-Q $\left.{ }^{\circledR}\right)$ and DNA extracted from B. bovis Ba48Aus and B. bigemina Bb35Th strains, provided by the Germplasm Bank of the Colombian Corporation of Farming Research (CORPOICA), were used as negative and positive control, respectively, for each PCR reaction performed in this study. 
The conditions for PCR tests were optimized based on the protocol reported by Adham et al. (2009). Each PCR reaction was perfomed in $25 \mu \mathrm{l}$ containing $1 \mathrm{X}$ buffer, $4 \mathrm{mM} \mathrm{MgCl}_{2}, 1 \mu \mathrm{M}$ of each primer, $0.65 \mathrm{U}$ of Taq DNA polymerase (Bioline, MA, USA), $0.4 \mathrm{mM}$ of dNTPs and 60ng of genomic DNA extracted from bovines or ticks' blood samples. The cycling conditions were: 10 min denaturation at $93^{\circ} \mathrm{C}$, followed by 35 cycles of 30 s denaturation at $93^{\circ} \mathrm{C}$, $30 \mathrm{~s}$ annealing at $49^{\circ} \mathrm{C}$, and $30 \mathrm{~s}$ extension at $72^{\circ} \mathrm{C}$, ending with a final extension at $72^{\circ} \mathrm{C}$ for $10 \mathrm{~min}$.

The amplification was confirmed by analyzing $5 \mu$ l of each PCR product through an electrophoresis on 1\% agarose gel stained with EZvision $^{\text {TM }}$ Dye (AMRESCO Inc. Cochran Road Solon, USA), as intercalating agent and visualized with Gel-Doc 2000 System (BIO-RAD, Hércules, CA.). Some amplification products, after selected randomly, were purified and bidirectional sequenced. The DNA sequences were edited, assembled and aligned using Geneious Pro 5.4.4 (Zupanska et al. 2009). A BLASTn (NCBI, GenBank) analysis was performed by following the same program and using the sequences obtained and reported by diverse studies all over the world, and provided by the GenBank for B. bovis and $B$. bigemina strains (Ríos \& Ríos 2011).

Parasitological indexes. In order to determine the infection in bovines, the results were reported in positivity terms and established the percentage of positive bovines by calculating the amount of Babesia sp. positive bovines over the total of bovines, multiplied by 100 . In order to determine the infection by Babesia $\mathrm{sp}$. in ticks, the results were reported in terms of positivity by calculating the amount of Babesia sp. positive ticks over the total of ticks, multiplied by 100 .

Entomological indicators. For evaluation of the entomological indicators, each bovine was searched from head to tail on their right sagittal plane. Sampled ticks were counted in the laboratory in order to establish ticks total, and according to this information, the herd infestation degree was established by means of the formula in Burgdogfer et al. (1970), considering the total number of ticks over the total number of bovines. In addition, Parasite burden per bovine was calculated considering the total number of ticks extracted from the sagittal plane of the animal X 2 (Álvarez et al. 2003).

Statistical analysis. The central tendency, position, and dispersion measures were determined for the quantitative variables. The association analysis was carried out through the estimation of Spearman-Rho correlation, according to the quantitative variables data distribution based on Shapiro-Wilk test, with a statistical significance level of $p \leq 0.05$. Also $\mathrm{Chi}^{2}$ tests and simple linear regressions were performed. Every statistical analysis was carried out by SPSS program, version 19, for Windows XP.
Ethical aspects. The Ethics Committee for Animal Experiments from the University of Antioquia granted an approval according to Act $\mathrm{N}^{\circ} 42$ issued on June $10^{\text {th }}, 2008$. The study included an informed consent form to be completed by the animal owners, that contained information related to research procedures and responsibilities. The Bioethics Committee assessed all ethical aspects in the project based on the Resolution 008430 issued in 1993 from the Ministry of Social Protection of Colombia, Title V - Animal Biomedical Research, and Law 84 issued in 1989, by which the National Statute for Animal Protection was adopted, as contraventions and regulations regarding procedures and competency were defined.

\section{RESULTS}

The research population consisted of 237 calves, aged from 3 to 9 months old, belonging to 9 herds in the area (Table 1). Most of the cattle were dual purpose, at a $76.4 \%$, followed by milk cattle at a $19.8 \%$, and exhibition cattle at a $3.8 \%$. None of the animals showed signs or symptoms for Babesiosis after medical - veterinary assessment.

The calves were distributed in three groups according to age range. Group 1 included 3 to 5-month-old calves, group 2, 6 to 7-month-olds and group 3, 8 to 9-month-olds. The percentage of calves for each one of these groups was $38.82 \%(92 / 237)$ in group 1, 37.97\% (90/237) in group 2, and $23.21 \%(55 / 237)$ in group 3 , from the bovines total. The mean age per heard and its standard deviation was calculated as shown in Table 1.

\section{Infection and infestation in cattle}

The infection in cattle was assessed by molecular techniques. PCR-amplified Babesia bovis and Babesia bigemina 18S rRNA gene partial sequence showed 63.3\% (150/237) positivity, in contrast to $59.9 \%(142 / 237)$ of the samples infected with B. bigemina, and a $3.4 \%$ (8/237) with mixed infection ( $B$. bigemina y $B$. bovis); positivity for $B$. bovis as only agent was not found and a $36.7 \%(87 / 237)$ negativity was detected (Table 1). The herd with highest percentage of infection was SA with $14.8 \%$ of the total of infected bovines. $B$. bigemina was the predominant parasite in all herds. The herd with lower percentage of infection was CB with $0.4 \%$ of the infection total. The herds with lower percentages of mixed infection were SL (2.1\%), LL (0.8\%) and EA $(0.4 \%)$ (Table 1$)$. The percentage of Babesia sp. infection

Table 1. Sampled bovine population distribution by age, distribution of ticks percentage and frequency of Babesia sp. infection in bovines and ticks per herd

\begin{tabular}{|c|c|c|c|c|c|c|c|}
\hline Herd & $\begin{array}{l}\text { Bovines: absolute } \\
\text { frequency } \\
\text { (relative frequency) }\end{array}$ & $\begin{array}{c}\text { Bovines: } \\
\text { Mean age in } \\
\text { months (SD) }\end{array}$ & $\begin{array}{c}\text { Babesia bigemina } \\
\text { infection } \\
\text { in bovines }(\%)\end{array}$ & $\begin{array}{c}\text { Mixed infection } \\
\text { in bovines } \\
(\%)\end{array}$ & $\begin{array}{c}\text { Ticks: absolute } \\
\text { frequency } \\
\text { (relative frequency) }\end{array}$ & $\begin{array}{c}\text { Babesia bigemina } \\
\text { infection } \\
\text { in ticks }(\%)\end{array}$ & $\begin{array}{c}\text { Mixed infection } \\
\text { in ticks } \\
(\%)\end{array}$ \\
\hline SA & 49 (20.7) & $6.94+/-1.197$ & $14.8(35 / 237)$ & 0 & $32(4.2)$ & 6.6 & 4.7 \\
\hline SL & $20(8.4)$ & $6.20+/-1.735$ & $3.8(9 / 237)$ & $2.1(5 / 237)$ & $48(6.2)$ & 8.5 & 0 \\
\hline $\mathrm{CN}$ & $128(5.1)$ & $4.50+/-1.168$ & $3.8(9 / 237)$ & 0 & $0(0)$ & - & - \\
\hline CB & $8(3.4)$ & $7.50+/-2.268$ & $0.4(1 / 237)$ & 0 & $10(1.3)$ & 2.9 & 2.9 \\
\hline LA & $31(13.1)$ & $5.00+/-1.612$ & $11(26 / 237)$ & 0 & $66(8.6)$ & 2.8 & 1.9 \\
\hline EA & $53(22.4)$ & $5.21+/-1.261$ & $12.2(29 / 237)$ & $0.4(1 / 237)$ & $420(54.5)$ & 30.2 & 0 \\
\hline LL & $18(7.6)$ & $7.44+/-1.653$ & $3.4(8 / 237)$ & $0.8(2 / 237)$ & $50(6.5)$ & 11.3 & 0 \\
\hline $\mathrm{LC}$ & $24(10.1)$ & $5.29+/-1.301$ & $4.2(10 / 237)$ & 0 & $86(11.2)$ & 7.5 & 1.9 \\
\hline B & $22(9.3)$ & $7.36+/-2.060$ & $6.3(15 / 237)$ & 0 & $58(7.5)$ & 9.4 & 0.0 \\
\hline Total & $237(100)$ & & & & $770(100)$ & & \\
\hline
\end{tabular}

$\overline{\mathrm{SD}}=$ Standard deviation. 
in bovines per age was $22.3 \%$ in cattle with 3 to 5 months, $24.5 \%$ in cattle with 6 to 7 months and $16.5 \%$ in cattle with 8 to 9 months. The distribution of infection per age groups was mostly caused by $B$. bigemina, being predominant in the first two groups. The mixed infection was found on low proportion in the three age groups (Fig.2). After a simple linear regression analysis, it was found that there is no statistic relation between the percentage of positive cattle and age of the animals $(p=0.261)$.

The degree of total infestation in the study area was 3.2 ticks per bovine. The degree of infestation per herd was also calculated, and according to this, the herd with higher infestation levels was EA with 7.9 ticks per bovine. The herd with lower degree of infestation was $\mathrm{CN}$, which showed negative results (Table 1). Regarding degree of infestation per age, group 2 presented the highest percentage of ticks, corresponding to $54 \%(416 / 770)$ of the total of ticks in the area. The degree of infestation in this group was 4 ticks per bovine. The calves in group 3 presented the lower degree of infestation with 1.7 ticks per bovine (Fig.3). There was no correlation between degree of infestation and age group (Rho: 0.221 y $p=0.001$ ). The herd that presented higher degree of infestation for 3 to 5-month-olds was LC, followed by LL y B. EA presented the highest degree of infestation in group 2. In turn, B presented the highest degree of infestation in group 3. CB only showed infestation in group

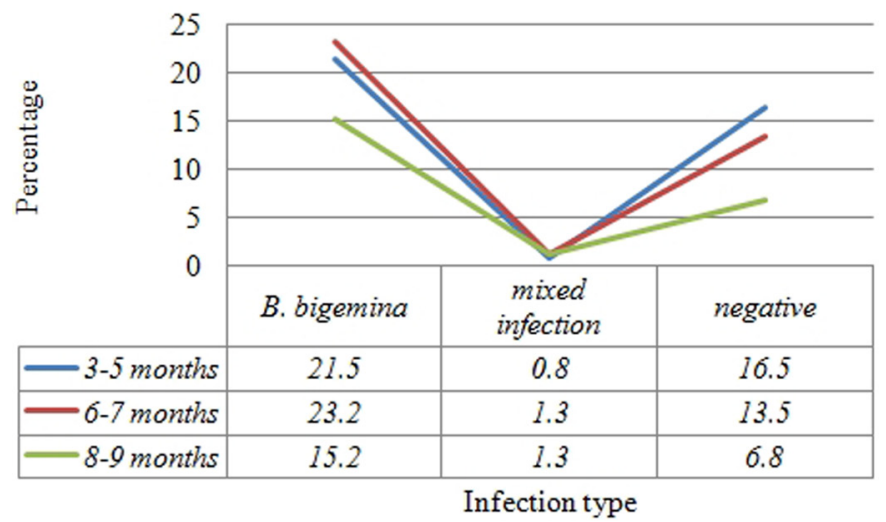

Fig.2. Distribution of Babesia sp. infection in cattle per age group in each herd.

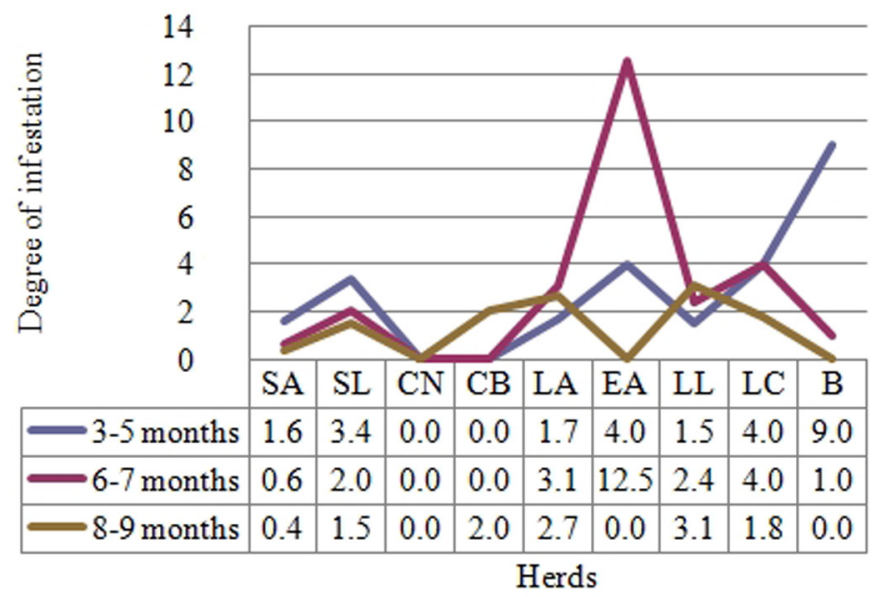

Fig.3. The degree of infestation per age group in each herd.
3 calves, whereas EA did not present infestation in this age group (Fig.3). After performing a simple linear regression analysis, no statistical relation between the percentage of positive ticks and age of animals was found $(p=0.711)$.

The total of ticks in each herd changed according to the type of cattle. 598 ticks representing $78 \%$ of the total were found in double purpose herds. In milk cattle herds, 106 ticks $(14 \%)$ were found. As these variables were analyzed, statistically significant differences were found between parasite burden and cattle type $(p=0.04)$. However, these numbers may vary as the year passes, which may be motivated not only on climatic factors, but also on subjective decisions taken by livestock farmers, regarding acaricides, based on infestation; such aspect avoids permanent exposure to ticks in the area. Likewise, factors such as the gathering of animals in wet areas inside the farm, where vegetation and microclimate are better and the possibilities of tick survival are higher, do not allow elimination by means of control strategies. On the contrary, some of them, such as excessive use of acaricides, instead of favoring animal health, affect their immunity.

\section{Infection in the vector}

The tick sample was composed by a total of 770 subjects that met the inclusion criteria. The percentage of ticks per herd, established as parasite burden, over the total of bovines in each herd, is shown on Table 1. As a result of evaluation, Babesia sp. infection were found in $88.6 \%$ positivity by means of DNA amplification, from which $79.2 \%$ corresponded to $B$. bigemina, $9.4 \%$ to mixed infection $(B$. bigemina, B. bovis) and there was $11.4 \%$ negativity. The herd with higher percentage of positive ticks was EA with $30.2 \%$, followed by LL and SA with $11.3 \%$. Mixed infection was found in 4 herds, from which SA had the highest proportion with $4.7 \%$ of the infected ticks. B. bigemina was the predominant parasite in every herd (Table 1).

The percentage of positivity per age group in each herd was calculated as the amount of positive ticks $R$. microplus collected, over the total amount of ticks collected. The age group that presented higher infection levels in its vectors was 6 to 7 months with a $40 \%$ of the total of collected ticks, followed by group 1 with $31.8 \%$. In the three age groups vectors, infection by B. bigemina was predominant; however, there was no statistical relation between the infection found in collected ticks and the age of bovines.

\section{Tick control acaricide}

In the herds observed, different chemical products such as tick control acaricides are employed to control the ectoparasites, by implementing diverse methods, concentrations, and frequencies of application. There are no standardized application protocols regarding doses and concentration in any herd, and that is why correlation between the degree of infestation and the tick control acaricide product used was not found (Rho: 0.0 ). The frequency of acaricide application varies from the moment the calf is 15 days to 2 years of age. A positive correlation between the frequency of the tick control acaricide and the infestation degree was found (Rho: 0.168 y $p=0.010$ ). 


\section{Analysis of partial sequences obtained from $18 S$ rRNA gene}

The BLASTn analysis of the partial nucleotidic sequences obtained from 18S rRNA gene for B. bigemina amplified strains, extracted from one tick and one cattle sampled from the herds, showed a 96\% identity with different species from the gender Babesia reported in the GenBank (NCBI). However, when BLASTn analysis was made, specifying that B. bigemina was the microorganism from which DNA were extracted, an $85.4 \%$ identity with $B$. bigemina strains reported throughout the world was found for both sequences - the ones coming from the vector and the bovine - in database GenBank, and an $86.9 \%$ identity with a $B$. bigemina strain (AY699276) (Buling et al. 2007) for both sequences. However, the quality of the sequences, obtained as a result of direct sequentiation of the PCR amplification products, was not assertive in some nucleotidic sites, probably because of it being an amplified product of a multicopy gene (Cowman et al. 1984, Adham et al. 2009).

\section{DISCUSSION}

The cattle areas that presented enzootic stability for bovine babesiosis are characterized by the permanent presence of ticks during the whole year, with little fluctuation that depends on climatic and ecological conditions, as well as on vector control (Alonso et al. 1992). These areas have been immunologically classified through a seroreactivity indicator by specific IgG antibodies against the parasite; values equal or higher than $75 \%$ in 3 to 9 -month-old animals determine the enzootic level in the region; however, it is necessary to consider the diverse factors involved in an enzootically stable area for bovine babesiosis, such as the parasite, the host and the vector (Oliveira et al. 2008).

The Middle Magdalena region is considered enzootically stable for bovine babesiosis, since the parasite presence in the area has been previously demonstrated based on serological techniques (Ríos et al. 2010). There is even previous research that reports the transmission to humans, showing the zoonotic potential of the bovine babesiosis in this region (Ríos et al. 2003). Generally, calves in the area are infected with $B$. bigemina and B. bovis during their first months, which explains the importance of the passive immunity transferred in the colostrum and that is considered active until the animal is 9 months old; all of this, together with natural exposure to sufficient levels of infected ticks enables development of efficient protective immunity against these parasites (Ríos et al. 2010; Oliveira et al. 2008).

The bovines selected for the area were left to graze since their first week, which means higher exposure to ticks and thus, higher probability of infection (Quintão-Silva and Ribeiro 2003). The infection in animals was diagnosed by molecular techniques; through multiplex PCR DNA amplification, a $63.3 \%$ positivity was established (150/237), determining a $59.9 \%(142 / 237)$ of infection by B. bigemi$n a$ and a $3.4 \%(8 / 237)$ of mixed infection (B. bigemina, $B$. bovis). These results are similar to the ones described by Costa-Júnior et al (2006).

The evaluation of infestation entomological indicators in bovines is related to another important factor in the epi- zootiology of the disease. This parameter was evaluated in the herds selected for the study and there was no correlation between the degree of infestation and the age of bovines, in spite of the 6 to 7 -month-old calves presenting a higher degree of infestation (4.7 ticks per bovine). These data are opposite to the ones described by Oliveira et al. (2005), where it was found that younger animals presented an infestation significantly lower to the presented in older bovines. All these findings indicate that younger bovines are more resistant to infestation, since they are exposed for a shorter time to the vectors.

Previous research suggests that the type of cattle is associated to the degree of infestation by ticks in bovines, by the condition of use of acaricides, together with the climatic conditions, that are not the same for all cattle types. For instance, in milk cattle, the excessive use of acaricides is related to babesiosis outbreaks (Quintão-Silva \& Ribeiro 2003). In the research area, there was correlation between the degree of infestation and cattle type (dual purpose and milk). A higher degree in dual purpose bovines $(p=0.04)$ is related with the distribution of the sampled cattle, since proportions were not paired and $78 \%$ of bovines selected make part of this type. The adoption of control strategies for ticks $R$. microplus, associated to chemical management methods have contributed to the establishment of enzootically unstable areas with low level in the antibody titers, showing an alteration in the development of protective immunity, which leads to an increase in the emergence of clinical cases of babesiosis (Quintão-Silva \& Ribeiro 2003, Brown et al. 2006).

Ríos et al. (2010) found a seroreactivity for B. bovis higher to $75 \%$ (enzootically stable) in 3 to 9 -month-old bovines that received tick control treatment at a frequency over 90 days, which is related with the conclusions of this study, since a positive correlation between higher tick control acaricide frequencies and the parasite burden was established (Rho: 0.168 and $p=0.010$ ). This situation reinforces the constant antigenic challenge for the bovine, due to the permanent presence of ticks that enable the transmission of the parasite to the babesiosis intermediary host.

All things considered, it can be inferred that a periodicity over 90 days for the tick control treatments, in enzootic areas for bovine babesiosis, constitutes an abiotic factor that enables the acquisition of protective immunity in bovines since early age, acting beneficially over the natural control of the infection and hence, the eventual absence of the disease signs and symptoms (Ríos et al. 2010). Consequently, there is a link between low frequency in tick control treatment and high levels of tick infestation in bovines and the development of enzootic stability in the area (Smith et al. 2000, Guerrero et al. 2007).

On the other hand, the absence of infestation in CN herd may be a risk factor for the outbreak of babesiosis. Since tick natural expression is avoided, calves are not exposed to tick inoculation, in this way reducing the antigenic challenge that stimulates the production of protective immunity to prevent the infection (Brown 2001, Brown, et al. 2006).

There are factors that may influence on the development and transmission of hemoparasites by their vector, 
among which we find: age of ticks and parasitemia stage in the host, since the tick needs to stay 24 hours on the animal during its highest parasitemia, in order to acquire the infection from the cattle (Oliveira-Sequeira et al. 2005). The percentage of positive ticks obtained in this study, was $86.8 \%$ of the total 770 collected ticks in the area.

B. bigemina was the predominant parasite in all herds, with $72.9 \%$ of the infection total. The age group that presented higher degree of infection in their vectors was group 2 with $40 \%$ of collected ticks, followed by group 1 with a $31.8 \%$. There was no statistical relation between the infection in the collected ticks in the different age groups and the age of the bovines; however, both the infection by $\mathrm{Ba}$ besia sp. and the infestation by $R$. microplus predominates in 6 to 7-month-old calves, in agreement with information reported by Rios et al. (2010).

Traditionally, the infection in bovines and ticks has been evaluated by means of direct microscopic techniques. However, and according to Quintão-Silva et al. (2007), the percentage of Babesia sp. infection in 3 to 9-month-old bovines through direct evaluation of blood by multiplex PCR DNA amplification, presented statistically significant differences between other techniques, increasing significantly the positive results through DNA amplification, which also allowed the identification of the circulating parasite species. Considering the specific result of the BLASTn analysis on the partial nucleotide sequences from the 18S rRNA gene obtained in this study for Babesia spp, this suggests that multiplex PCR technique can be used successfully for the analysis of babesiosis in endemic tropical areas in Colombia, both in intermediate and definitive hosts.

In every herd and each group, the subjects presented a higher positivity percentage and there was evidence that none of the animals was only infected by $B$. bovis; the animals carrying this parasite had a concomitant infection by $B$. bigemina, in accordance to reports by Oliveira-Sequeira et al. (2005), Adham et al. (2009), Costa-Júnior et al. (2006). These researchers found out that mixed infections are presented in lower proportions than infections caused by individual species, both in bovines and ticks. A similar situation was evident through the infection behavior in ticks where the vectors in every herd and every age group showed a higher positivity percentage through multiplex PCR.

The findings regarding the negativity for $B$. bovis in comparison with the high positivity for $B$. bigemina in the sampled animals may be parallel to those reported by Mtshali \& Mtshali (2013). The ability of B. bigemina to remain through generations of ticks in absence of reinfection, which is not a characteristic of B. bovis, may be the cause for such results. In addition, the high degree of pathogenicity for $B$. bovis facilitates its identification and elimination by the immune system, which leads to low parasitemia.

All things considered, it would be required to increase the level of infestation by ticks in order to ensure the preservation of infection by B. Bovis and thus the generation of enzootic stability for this parasite in the herds. However, modifying the frequencies of tick control acaricide application to obtain a high degree of infestation and consequen- tly, guarantee high parasitemias for B. bovis, could affect the enzootic stability for B. bigemina.

These results also show the need of other epizootiologic research in other livestock farming regions, in order to determine the levels of enzootic stability. It may be possible by evaluating the entomological and parasitological indicators established in this study, whose instability inflicts on the clinical manifestation of bovine babesiosis (Ríos et al. 2010).

Acknowledgements.- This research was supported by Comité para el Desarrollo de la Investigación (CODI), Universidad de Antioquia, Grant number CIEM-13-09. We thank the Microorganism Germoplasm Bank - Ecto and Hemo parasites in Colombian Corporation of Agricultural Research (Corpoica) and the owners of the herds chosen for this research and the administrative and technical staff in the farms for their invaluable cooperation in the field, and the Regional Cooperative Society of Livestock Farmers (Coregan) in the Middle Magdalena Region.

\section{REFERENCES}

Álvarez V., Bonilla R. \& Chacón I. 2003. Frecuencia relativa de Boophilus microplus (Acari: Ixodidae) en bovinos (Bos taurus y B. indicus) en ocho zonas ecológicas de Costa Rica. Revta Biol. Trop. 51(2):427-434.

Adham F., Abd-El-Samie E., Gabre R. \& El Hussein H. 2009. Detection of tick blood parasites in Egypt using PCR assay I-Babesia bovis and Babesia bigemina. Parasitol. Res. 105(3):721-730.

Alonso M., Arellano-Sota C., Cereser V., Cordoves C., Guglielmone A., Kessler R., Mangold A., Nari A., Patarroyo J. \& Solari M. 1992. Epidemiology of bovine anaplasmosis and babesiosis in Latin America and the Caribbean. Rev. Sci. Technol. 11(3):713-733.

Barreira J., Rossi M., Pires F., Silva G. \& Massard C. 2005. Dinâmica da infecção de Babesia bovis (Babés, 1888, Starcovici, 1893) em fêmeas ingurgitadas e ovos de Boophilus microplus (Canestrini, 1887). Ciência Rural 35(5):1131-1135. <http://www.scielo.br/scielo.php?script=sci_arttext \&pid=S0103-84782005000500022 \&lng=en\&nrm=iso> Access Aug, 5, 2011.

Barros S., Madruga C., Araújo F., Menk C., Almeida M., Melo E. \& Kessler R. 2005. Serological survey of Babesia bovis, Babesia bigemina, and Anaplasma marginale antibodies in cattle from the semi-arid region of the state of Bahia, Brazil, by enzyme-linked immunosorbent assays. Mem. Inst. Oswaldo Cruz 100(6):513-517.

Brown W. 2001. Molecular approaches to elucidating innate and acquired immune responses to Babesia bovis, a protozoan parasite that causes persistent infection. Vet. Parasitol. 101(3/4):233-248.

Brown W., Norimine J., Knowles D. \& Goff W. 2006. Immune control of Babesia bovis infection. Vet. Parasitol. 138(1/2):75-87.

Buling A., Criado-Fornelio A., Asenzo G., Benitez D., Barba-Carretero J. \& Florin-Christensen M. 2007. A quantitative PCR assay for the detection and quantification of Babesia bovis and B. bigemina. Vet. Parasitol. 147(1/2):16-25.

Burdogfer W. 1970. Hemolymph test a technique for detection of rickettsiae in ticks. Am. J. Trop. Med. Hyg. 19(6):1010-1014.

Cantu A., Ortega S.J., Mosqueda J., Garcia-Vazquez Z., Henke S. \& George J. 2007. Immunologic and molecular identification of Babesia bovis and Babesia bigemina in free-ranging white-tailed deer in northern Mexico. J. Wildl. Dis. 43(3):504-507.

Costa-Júnior L., Rabelo E., Martins F., Martins O. \& Ribeiro M. 2006. Comparison of different direct diagnostic methods to identify Babesia bovis and Babesia bigemina in animals vaccinated with live attenuated parasites. Vet. Parasitol. 139(1/3):231-236.

Cowman A., Bernard O., Stewart N. \& Kemp D. 1984. Genes of the protozoan parasite Babesia bovis that rearrange to produce RNA species with different sequences. Cell 37(2):653-660.

Guerrero F., Bendele K., Davey R. \& George J. 2007. Detection of Babesia bigemina infection in strains of Rhipicephalus (Boophilus) microplus 
collected from outbreaks in South Texas. Vet. Parasitol. 145(1/2):156163.

Guglielmone A., Gaido A. \& Mangold A. 1996. Light microscopy diagnosis of Babesia bovis and Babesia bigemina kinetes in the hemolymph of artificially infected Boophilus microplus engorged female ticks. Vet. Parasitol. 61(1/2):15-20.

Gómez L. 2005. Las fronteras de Antioquia. La Frontera Antioquia-Santander: aspectos físicos, jurídicos, históricos, económicos y socioculturales. Departamento Administrativo de Planeación. Gobernación de Antioquia, p.1-80.

Melendez R. \& Forlano M. 1996. Incidence and intensity of Babesia spp. sporokinetes in engorged Boophilus microplus from a dairy herd in Venezuela. Ann. N.Y. Acad. Sci. 791:148-156.

Morzaria S., Katende J., Kairo A., Nene V. \& Musoke A. 1992. New methods for the diagnosis of Babesia bigemina infection. Mem. Inst. Oswaldo Cruz 87(3):201-205.

Morzaria S., Katende J., Kairo A., Nene V., Musoke A., Skilton R. \& Bishop R. 1999. Development of sero-diagnostic and molecular tools for the control of important tick-borne pathogens of cattle in Africa. Parassitologia 41(Suppl.1):73-80.

Mtshali M.S. \& Mtshali P.S. 2013. Molecular diagnosis and phylogenetic analysis of Babesia bigemina and Babesia bovis hemoparasites from cattle in South Africa. BMC Vet. Res. 9:154.

Oliveira M., Oliveira-Sequeira T., Regitano L., Alencar M., Neo T., Silva A. \& Oliveira H. 2008. Detection of Babesia bigemina in cattle of different genetic groups and in Rhipicephalus (Boophilus) microplus tick. Vet. Parasitol. 155(3/4):281-286.

Oliveira M.C., Oliveira-Sequeira T.C., Araujo J., Amarante A. \& Oliveira H. 2005. Babesia spp. infection in Boophilus microplus engorged females and eggs in São Paulo State, Brazil. Vet. Parasitol. 130(1/2):61-67.

Quintao-Silva M., Melo M. \& Ribeiro M. 2007. Comparison of duplex PCR and microscopic techniques for the identification of Babesia bigemina and Babesia bovis in engorged female ticks of Boophilus microplus. Zoonoses Publ. Health 54(3/4):147-151.

Quintão-Silva M. \& Ribeiro M. 2003. Infection rate of Babesia spp. sporokinetes in engorged Boophilus microplus from an area of enzootic stability in the State of Minas Gerais, Brazil. Mem. Inst. Oswaldo Cruz 98(8):999-1002.

Ravindran R., Rao J. \& Mishra A. 2006. Detection of Babesia bigemina DNA in ticks by DNA hybridization using a nonradioactive probe generated by arbitrary PCR. Vet. Parasitol. 141(1/2):181-185.

Ríos L., Álvarez G. \& Blair S. 2003. Serological and parasitological study and report of the first case of human babesiosis in Colombia. Revta Soc. Bras. Med. Trop. 36(4):493-498. <http://www.scielo.br/scielo.php?script=sci_ arttext\&pid=S0037-86822003000400010\&lng=en > Access Apr. 17, 2011.

Ríos L., Zapata R., Reyes J., Mejía J. \& Baena A. 2010. Estabilidad enzoótica de babesiosis bovina en la región de Puerto Berrío, Colombia. Revta Cient., Maracaibo, 20(5):485-492.

Ríos S. \& Ríos L. 2011. Principal molecular markers used to identify Babesia bovis and Babesia bigemina. Revta MVZ Córdoba 16(2):2470-2483.

Rosero D., Gutiérrez L., Cienfuegos V., Jaramillo L. \& Correa M. 2010. Optimization of a DNA extraction procedure for anopheline mosquitoes. Colombia. Revta Colomb. Entomol. 36:260-263.

Smith R., Evans D., Martins J., Ceresér V., Correa B., Petraccia C., Cardozo H., Solari M. \& Nari A. 2000. Babesiosis (Babesia bovis) stability in unstable environments. Ann. N.Y. Acad. Sci. 916:510-520.

Villafañe C. \& Posso D. 2009. Protocolos de extracción de ADN total de animales método de Salting Out. Protocolos de laboratorio UEG [monograph on the Internet]. Instituto Venezolano de Investigaciones Científicas, Altos de Pipe, Venezuela <http://www.ivic.gob.ve/ecologia/ueg/> Access Apr. 9, 2011.

Zupanska A., Drummond P., Swetnam D., Al-Khedery B. \& Allred D. 2009. Universal primers suitable to assess population dynamics reveal apparent mutually exclusive transcription of the Babesia bovis ves1[alpha] gene. Mol. Biochem. Parasitol. 166(1):47-53. 